Supporting Information for

\title{
Overestimation of Monoterpene Organosulfate Abundance in Aerosol Particles by Sampling in the Presence of $\mathrm{SO}_{2}$
}

prepared for Environmental Science \& Technology Letters

Martin Brüggemann ${ }^{1}$, Matthieu Riva ${ }^{2}$, Sébastien Perrier ${ }^{2}$, Laurent Poulain ${ }^{1}$, Christian George ${ }^{2}$, Hartmut Herrmann ${ }^{1, *}$

${ }^{1}$ Leibniz Institute for Tropospheric Research (TROPOS), Atmospheric Chemistry Department (ACD), Permoserstr. 15, 04318 Leipzig, Germany

2Univ Lyon, Université Claude Bernard Lyon 1, CNRS, IRCELYON, F-69626, Villeurbanne, France

*Correspondence to: herrmann@tropos.de 


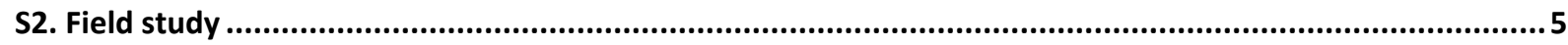

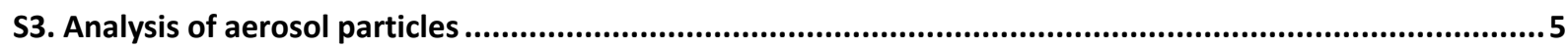

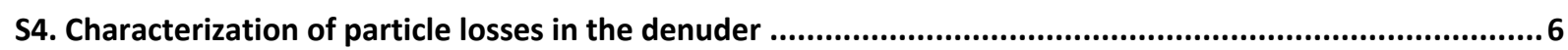

Figure S1. (a) Schematic of the ACD chamber setup. (b) Schematic of the dual filter sampling unit that was used to sample particles in the presence and in the absence of gas-phase $\mathrm{SO}_{2}$

Figure S2. Long-term validation of the $\mathrm{SO}_{2}$ removal efficiency of the annular glass denuder coated with $\mathrm{Na}_{2} \mathrm{CO}_{3}$ at $\mathrm{SO}_{2}$ levels of up to $30 \mathrm{ppb}$ (panel a) and $15 \mathrm{ppb}$ (panel b). After $\mathrm{SO}_{2}$ was injected, chamber air was sampled either without (gray areas) or with the denuder (white areas) at $18 \mathrm{~L} \mathrm{~min}^{-1}$ and corresponding $\mathrm{SO}_{2}$ levels in the sample flow were monitored.

Figure S3. Particle losses in the denuder at different flow rates.

Figure S4. Detection of particulate sulfate from filter samples for various oxidants and seed particle acidities with and without $\mathrm{SO}_{2}$ removal through the denuder. Total peak areas of sulfate (detected as $\mathrm{HSO}_{4}^{-}, \mathrm{m} / \mathrm{z}$ 96.9601) are normalized to the particle mass concentration during filter sampling. Error bars depict maximum denuder losses of up to $10 \%$.

Figure S5. Predicted isotopic pattern (green) and observed ion signals (blue) from LC-MS measurements for common $\mathrm{OS}$ species detected in $\mathrm{OH}$ oxidation experiments.

Figure S6. Predicted isotopic pattern (green) and observed ion signals (blue) from LC-MS measurements for common OS species detected in $\mathrm{O}_{3}$ oxidation experiments.

Figure S7. Predicted isotopic pattern (green) and observed ion signals (blue) from LC-MS measurements for common $\mathrm{OS}$ species detected in $\mathrm{NO}_{3}$ oxidation experiments.

Figure S8. Detection of MT-OSs from PTFE filter samples with and without $\mathrm{SO}_{2}$ removal through the denuder during the field study (daytime and nighttime samples are indicated by " $D$ " and " $N$ ", respectively). Panel a) Abundance of detected OSs normalized to the average $\mathrm{PM}_{2.5}$ mass during the sampling time. Panel b) Relative difference between the sample types in normalized OS abundances for each sampling period. Average values for $\mathrm{SO}_{2}$ levels and relative humidity are given on the second y-axes.

Figure S9. Number of detected MT-OSs from quartz (panel a) and PTFE (panel b) filter samples with and without $\mathrm{SO}_{2}$ removal through the denuder during the field study (daytime and nighttime samples are indicated by " $D$ " and "N", respectively)

Figure S10. $\mathrm{PM}_{2.5}$-normalized abundance of MT-OSs for quartz filter samples as a function of $\mathrm{SO}_{2}$ levels (i.e., with and without $\mathrm{SO}_{2}$ removal). The dashed lines show linear regression fits for each sample type.

Figure S11. $\mathrm{PM}_{2.5}$-normalized abundance of MT-OSs for PTFE filter samples as a function of $\mathrm{SO}_{2}$ levels (i.e., with and without $\mathrm{SO}_{2}$ removal). The dashed lines show linear regression fits for each sample type.

Figure S12. Correlation plots for quartz filter samples from the field study. Artifact formation as a function of relative humidity in relative (panel a) and absolute (panel c) differences of normalized MT-OS abundances. Artifact formation as a function of $\mathrm{SO}_{2}$ levels in relative (panel b) and absolute (panel d) differences of normalized MT-OS abundances.

Figure S13. Correlation plots for PTFE filter samples from the field study. Artifact formation as a function of relative humidity in relative (panel a) and absolute (panel c) differences of normalized MT-OS abundances. Artifact formation as a function of $\mathrm{SO}_{2}$ levels in relative (panel b) and absolute (panel d) differences of normalized MT-OS abundances.

Table S1. Overview on experimental conditions of the chamber runs and the corresponding filter samples analyzed by LC-MS.

Table S2. LC-MS enhancement factors for particle mass-normalized peak areas of single OS species in the presence of $15 \mathrm{ppb} \mathrm{SO}_{2}$ during filter sampling. OSs that were only detectable in presence of $\mathrm{SO}_{2}$ are denoted with "+". 
Table S3. Comparison of direct infusion-ESI-MS and LC-ESI-MS on the number of detected of OSs in filter extracts from the chamber experiments.

Table S4. OS signals displayed in Figure 2a, which were increasing upon removal of the charcoal denuder during $\mathrm{OH}$ oxidation of $\alpha$-pinene in the presence of $\mathrm{NO}_{x}$ and $\mathrm{SO}_{2}$.

Table S5. OS signals displayed in Figure 2b, which were increasing upon removal of the charcoal denuder during the ozonolysis of $\alpha$-pinene in the presence of $\mathrm{NO}_{x}$ and $\mathrm{SO}_{2}$.

Table S6. OS signals displayed in Figure 2c, which were increasing upon removal of the charcoal denuder during $\mathrm{NO}_{3}$ oxidation of $\alpha$-pinene in the presence of $\mathrm{SO}_{2}$.

Table S7. Overview on average values for meteorological parameters, $\mathrm{PM}_{2.5}$ mass concentrations, and trace gas levels during the filter sampling periods at the Melpitz field station. 


\section{S1. Chamber experiments}

All laboratory experiments were conducted in the TROPOS-ACD chamber (ACD-C), which consists of a cylindrical Teflon bag with a volume of $19 \mathrm{~m}^{3}$ and a surface-to-volume ratio of $2 \mathrm{~m}^{-1}$ (Figure S1a). Further technical details can be found elsewhere. ${ }^{1}$ The chamber was run as a continuously stirred tank reactor (CSTR) with a flow rate of $190 \mathrm{~L} \mathrm{~min}^{-1}$ resulting in an average residence time of $100 \mathrm{~min}$ for aerosol components. Particle size and volume distribution were continuously monitored by a scanning mobility particle sizer (SMPS) in the range of $10-800 \mathrm{~nm}$. If not stated otherwise, temperature and relative humidity $(\mathrm{RH})$ were adjusted to $21 \pm 2{ }^{\circ} \mathrm{C}$ and $55 \pm 5 \%$, respectively. Steady-state mixing ratios of $60-100 \mathrm{ppb} \alpha$-pinene and $15 \mathrm{ppb}$ of both $\mathrm{SO}_{2}$ and $\mathrm{NO}$ were used. Because of their high vapor pressure and low solubility, $\alpha$-pinene and NO can be expected to remain almost entirely in the gas phase without significant interactions with the sampled particulate-phase material on the filter substrate. In contrast, $\mathrm{SO}_{2}$ can be expected to rapidly dissolve into the aqueous phase, e.g., Jayne et $a .^{2}$ suggest equilibration times for $\mathrm{SO}_{2}$ dissolution at the water surface in the range of microseconds. Similarly, oxygenated VOCs from $\alpha$-pinene oxidation may dissolve and interact with sampled particles, as demonstrated by Kristensen. ${ }^{3}$ Nonetheless, no significant effects from differences in $\alpha$-pinene levels were observed, and thus, were neglected during the further analysis. Seed particles were injected by nebulization of aqueous solutions of $\mathrm{Na}_{2}{ }^{34} \mathrm{SO}_{4}$ and $\mathrm{H}_{2} \mathrm{SO}_{4}$ in different ratios to vary particle acidity (Table S1), yielding particle mass concentrations of $67 \pm 38 \mu \mathrm{g} \mathrm{m}^{-3}$ (i.e., assuming an average particle density of $2 \mathrm{~g} \mathrm{~cm}^{-3}$ ). Hydroxyl radicals $(\mathrm{OH})$ were produced from either iso-propyl nitrite or $\mathrm{H}_{2} \mathrm{O}_{2}$ photolysis, giving steady-state concentrations of about $4.2 \times 10^{6} \mathrm{OH} \mathrm{cm}^{-3}$, estimated based on gasphase model calculations. ${ }^{4}$ Ozone was produced by photolysis of $\mathrm{O}_{2}$, which was guided through a UV lamp, giving steady-state $\mathrm{O}_{3}$ mixing ratios of about $100 \mathrm{ppb}$ in the chamber. $\mathrm{No} \mathrm{OH}$ scavengers were used in the experiments. Production of nitrate radicals $\left(\mathrm{NO}_{3}\right)$ was performed in an external pre-reactor, in which $\mathrm{NO}_{2}$ and $\mathrm{O}_{3}$ were injected, eventually yielding an estimated steady-state concentration of about $1.8 \times 10^{9} \mathrm{NO}_{3} \mathrm{~cm}^{-3}$ in the chamber. A detailed overview on experimental conditions is given in Table S1.

A dual filter sampling setup was applied to investigate the effect of $\mathrm{SO}_{2}$ on OS abundance in the sampled particle mass. Figure $\mathrm{S} 1 \mathrm{~b}$ shows a schematic of the setup, where $\mathrm{SO}_{2}$ was removed prior to particle collection in one of the channels by an annular glass denuder coated with $\mathrm{Na}_{2} \mathrm{CO}_{3}$. The glass surface of the denuder was coated with a solution of $1 \%(\mathrm{w} / \mathrm{v}) \mathrm{Na}_{2} \mathrm{CO}_{3}, 1 \%(\mathrm{v} / \mathrm{v})$ glycerol in methanol/water (1:1). ${ }^{5}$ The $\mathrm{SO}_{2}$ removal efficiency of the denuder was extensively tested prior to the chamber experiments under much higher $\mathrm{SO}_{2}$ levels of up to $30 \mathrm{ppb}$ and extended sampling periods of up to 24 hours (Figure S2). During the chamber experiments, particles were collected in parallel on 
both channels of the sampling system on borosilicate glass fiber filters coated with PTFE (47 $\mathrm{mm}$ in diameter, PG-60, PALL, USA) at a flow rate of $18 \mathrm{~L} \mathrm{~min}^{-1}$ for 30 minutes.

\section{S2. Field study}

Field samples were taken during $15-27$ July 2020 at the TROPOS research station Melpitz $\left(51.5254^{\circ} \mathrm{N}\right.$, $12.9276^{\circ} \mathrm{E}, 86 \mathrm{~m}$ a.s.I.) in Germany, which is a representative rural background site for Central Europe. A detailed description of the site can be found elsewhere. ${ }^{6}$ Particle sampling was conducted downstream of a $\mathrm{PM}_{2.5}$ pre-separator using the same dual sampling setup as during the chamber studies (i.e., one channel equipped with the $\mathrm{Na}_{2} \mathrm{CO}_{3}$ denuder and one bypass channel; Figure $\mathrm{S} 1 \mathrm{~b}$ ). However, due to technical reasons, the sampling flow rate through the filters was decreased to $8.0 \mathrm{~L}$ $\mathrm{min}^{-1}$. In the first part of the field campaign, from 15 to 20 July 2020, aerosol particles were sampled on PTFE filters (glass fiber filters with PTFE coating, PG-60, Pall, USA) separately during daytime (8:00-16:00 CEST) and nighttime (20:00-04:00 CEST). In the second part, from 21 to 27 July 2020, particles were sampled on pre-baked quartz fiber filters (MK360, Munktell, Sweden) separately during daytime (8:00-16:00 CEST) and nighttime (20:00-04:00 CEST). During 18-20 July (PTFE filters) and 2527 July (quartz filters) daytime and nighttime samples were collected for 3 subsequent days and nights, respectively, on the same filter to accumulate more particle mass, ensuring that also for less abundant MT-OSs the corresponding concentrations were well above the detection limit. An overview of average values for meteorological parameters, $\mathrm{PM}_{2.5}$ mass concentrations, and trace gas levels during the filter sampling periods is given in Table S7.

\section{S3. Analysis of aerosol particles}

After particle collection, the samples were directly placed into glass petri-dishes, sealed with Parafilm ${ }^{\circledR}$, and wrapped in aluminum foil. Subsequently, the samples were stored in a freezer at $-21{ }^{\circ} \mathrm{C}$ for a maximum of 5 days. For the extraction, half of a filter was cut into small pieces, transferred into a 4 $\mathrm{mL}$ brown glass vial to which $1 \mathrm{~mL}$ of $\mathrm{ACN} / \mathrm{H}_{2} \mathrm{O}$ (1:1) was added. The extraction vial was agitated at 1000 rounds per minute for 30 minutes. Afterwards, the extract was filtered using a syringe filter (pore size $=0.2 \mu \mathrm{m}$, Acrodisc GHP membrane, Pall Corporation) to remove any suspended particulate material that would clog the LC column. For the analysis of the extracts by liquid chromatography (LC) coupled with high resolution Orbitrap MS (Q Exactive Orbitrap Plus, Thermo Fisher Scientific, US) full scan and all-ion-fragmentation spectra were acquired. Characteristic fragments of $\mathrm{OSs}$ in $\mathrm{MS}^{2}$ (i.e., $\mathrm{SO}_{3}{ }^{-}$ , $\mathrm{SO}_{4}{ }^{-}, \mathrm{HSO}_{4}{ }^{-}$) were used to identify single OSs, ${ }^{7}$ whereas quantification was carried out using corresponding $[\mathrm{M}-\mathrm{H}]^{-}$signals in full scan spectra. To account for different particle loadings, peak areas were normalized to particle mass concentrations, treating particle density as a constant (i.e., density = $2 \mathrm{~g} \mathrm{~cm}^{-3}$ ) close to the densities of $\mathrm{Na}_{2} \mathrm{SO}_{4}$ and $\mathrm{H}_{2} \mathrm{SO}_{4}$. For the analysis of filter extracts by direct infusion 
ESI-Orbitrap MS, $25 \mu \mathrm{L}$ of the extract were injected into a flow of $A C N / H_{2} \mathrm{O}(1: 1)$ at a flow rate of $0.3 \mathrm{~mL} \mathrm{~min}{ }^{-1}$ that was transferring the sample into the ESI probe. All mass spectrometric settings were the same as for the analysis by LC-Orbitrap MS. Prior to all measurements, the mass spectrometer was calibrated using a series of sodium acetate clusters, commonly yielding a mass accuracy of $\leq 2 \mathrm{ppm}$. Mass spectrometric signals with intensities below $10^{3}$ a.u. in fullMS were treated as noise. For the field samples, OSs with 8-10 carbon atoms in the assigned molecular formula were regarded as monoterpene-derived OSs (MT-OSs) and further investigated. Potential OSs with lower and higher carbon numbers were ignored in the subsequent data analysis. Further details on the identification of MT-OSs and the analysis method can be found elsewhere. ${ }^{8}$

Online analysis of aerosol particles was conducted by extractive electrospray ionization (EESI) coupled with Orbitrap MS similar to Lee et al. ${ }^{9}$ However, to allow the detection of OSs as $[\mathrm{M}-\mathrm{H}]^{-}$ion signals, the EESI source was run in negative mode. In contrast to the filter sampling setup, a multi-channel charcoal denuder was optionally installed directly in front of the ion source to study the effect of gasphase $\mathrm{SO}_{2}$ on EESI. The $\mathrm{SO}_{2}$ removal efficiency of the charcoal denuder was found to be $>90 \%$. For all experiments, an 8:2 (v/v) mixture of acetonitrile and water with $0.1 \%$ formic acid was used as the electrospray solution. An external negative voltage of 2.9-3.3 kV was applied to the reservoir bottle. The ion-transfer capillary was held at $350^{\circ} \mathrm{C}$ to evaporate charged droplets. The mass resolving power, ion injection time, and microscan count of the Q Exactive Plus Orbitrap were set to 140,000 at $\mathrm{m} / \mathrm{z} 200$, $1000 \mathrm{~ms}$, and 5 , respectively, giving full scan spectra from $\mathrm{m} / \mathrm{z} 50$ to 750 roughly every 5 seconds. More details on the applied Orbitrap settings and how they affect the data acquisition can be found elsewhere. ${ }^{9,10}$

\section{S4. Characterization of particle losses in the denuder}

For the characterization of particle losses in the denuder, ammonium sulfate seed particles were introduced into the chamber by nebulization of a solution containing $7.94 \mathrm{~g} / \mathrm{L}\left(\mathrm{NH}_{4}\right)_{2} \mathrm{SO}_{4}$ and $20 \mu \mathrm{l} / \mathrm{L}$ $\mathrm{H}_{2} \mathrm{SO}_{4}$. The resulting particle number size distribution was measured subsequently with and without the denuder installed in front of the SMPS. Denuder flow rates of 8 and $18 \mathrm{~L} \mathrm{~min}^{-1}$ were investigated, i.e., mimicking field and laboratory conditions, respectively. As shown in Figure S3, at both flow rates, particle wall losses were negligible (i.e., 1\%) over the entire size range from 10-800 nm, giving a maximum in particle number losses of $12 \%$ for particles in the size range of $30-50 \mathrm{~nm}$ at a denuder flow rate of $18 \mathrm{~L} \mathrm{~min}^{-1}$. 


\section{a)}

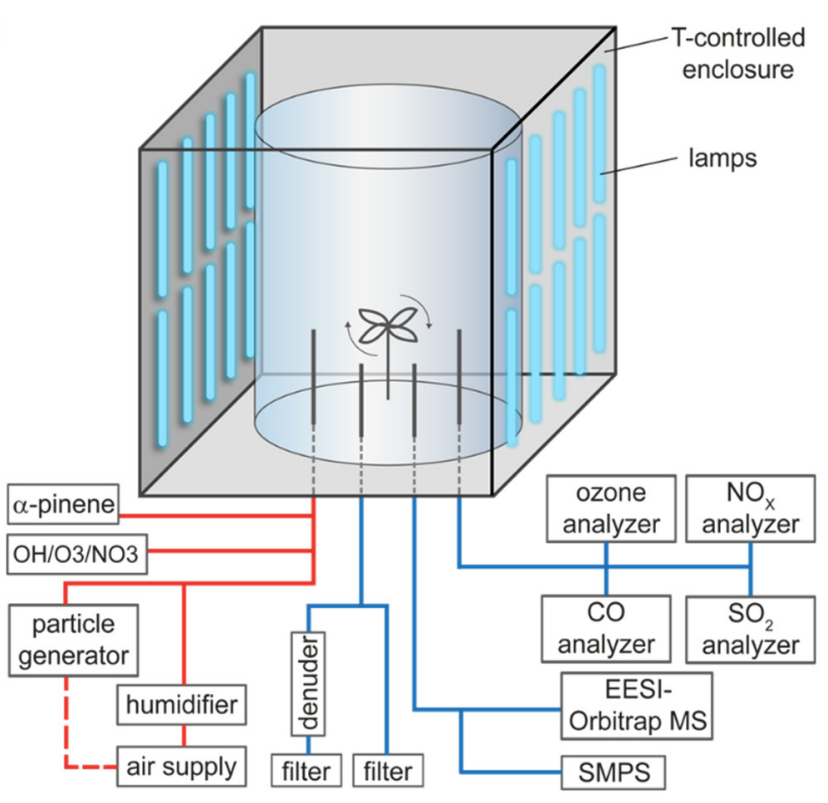

b)

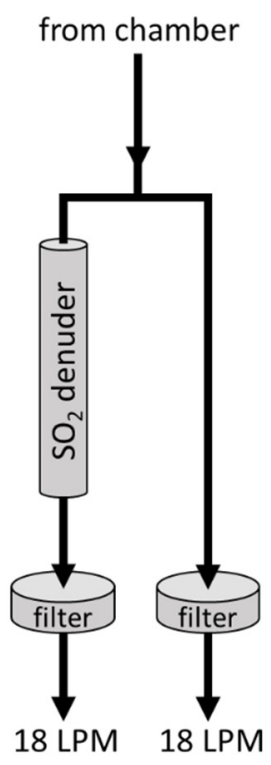

Figure S1. (a) Schematic of the ACD chamber setup. (b) Schematic of the dual filter sampling unit that was used to sample particles in the presence and in the absence of gas-phase $\mathrm{SO}_{2}$.
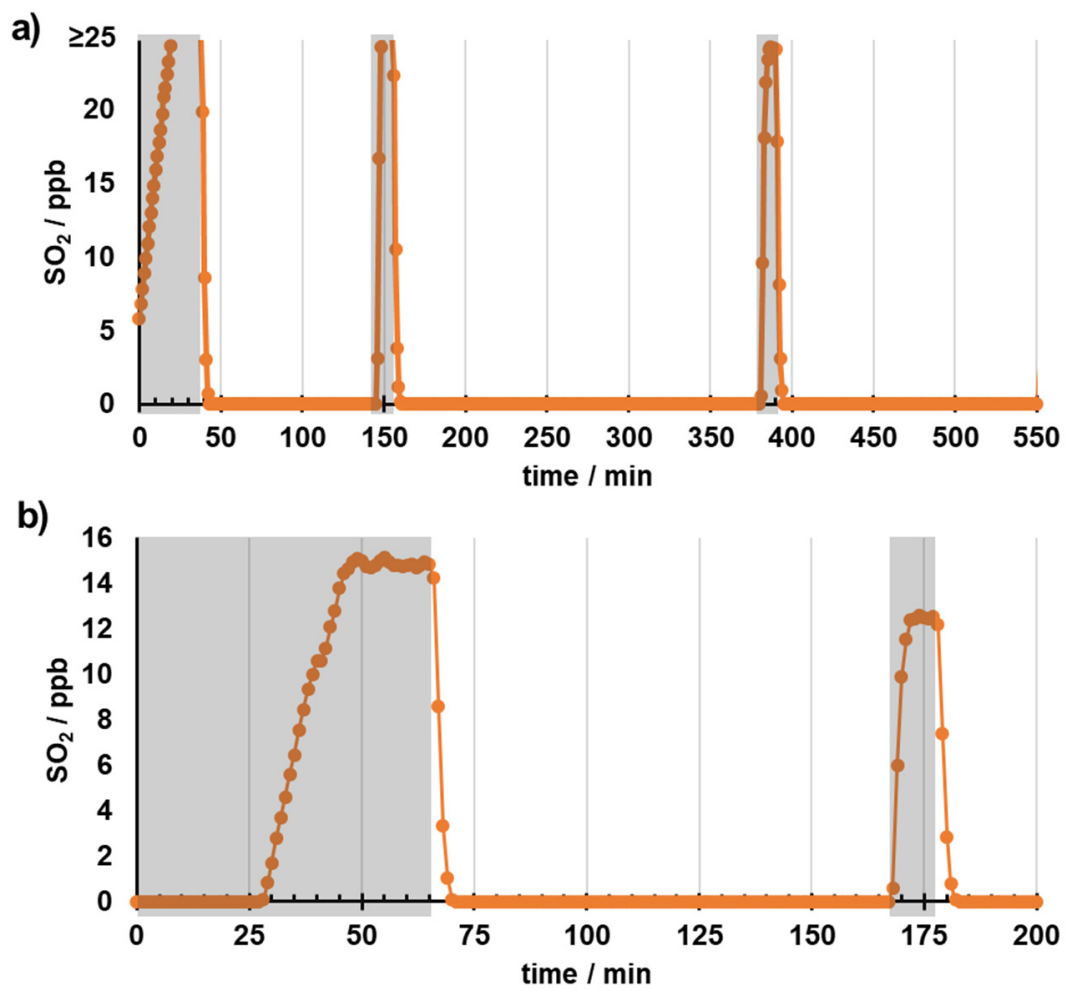

Figure S2. Long-term validation of the $\mathrm{SO}_{2}$ removal efficiency of the annular glass denuder coated with $\mathrm{Na}_{2} \mathrm{CO}_{3}$ at $\mathrm{SO}_{2}$ levels of up to $30 \mathrm{ppb}$ (panel a) and $15 \mathrm{ppb}$ (panel b). After $\mathrm{SO}_{2}$ was injected, chamber air was sampled either without (gray areas) or with the denuder (white areas) at $18 \mathrm{~L} \mathrm{~min}^{-1}$ and corresponding $\mathrm{SO}_{2}$ levels in the sample flow were monitored. 

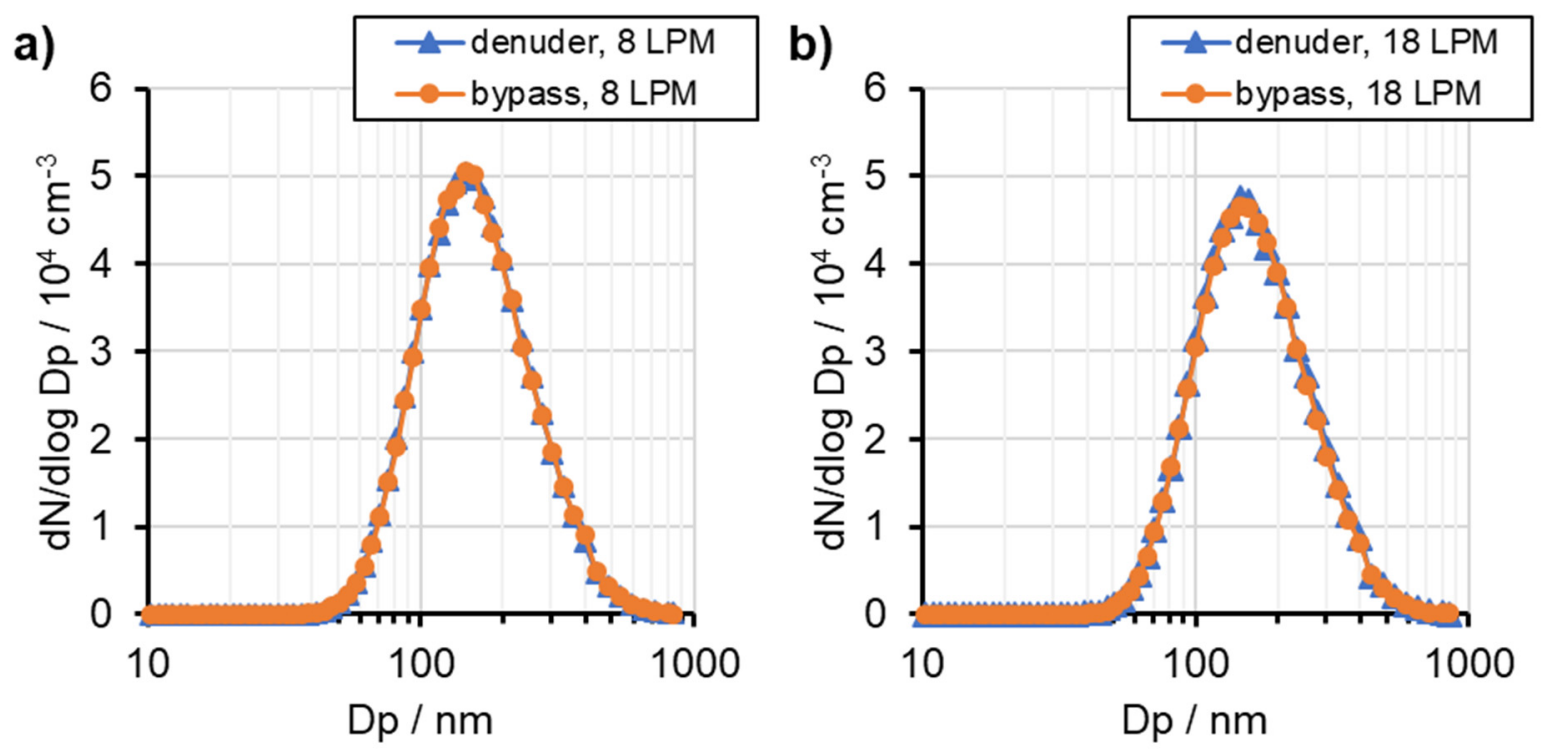

Figure S3. Particle losses in the denuder at different flow rates.

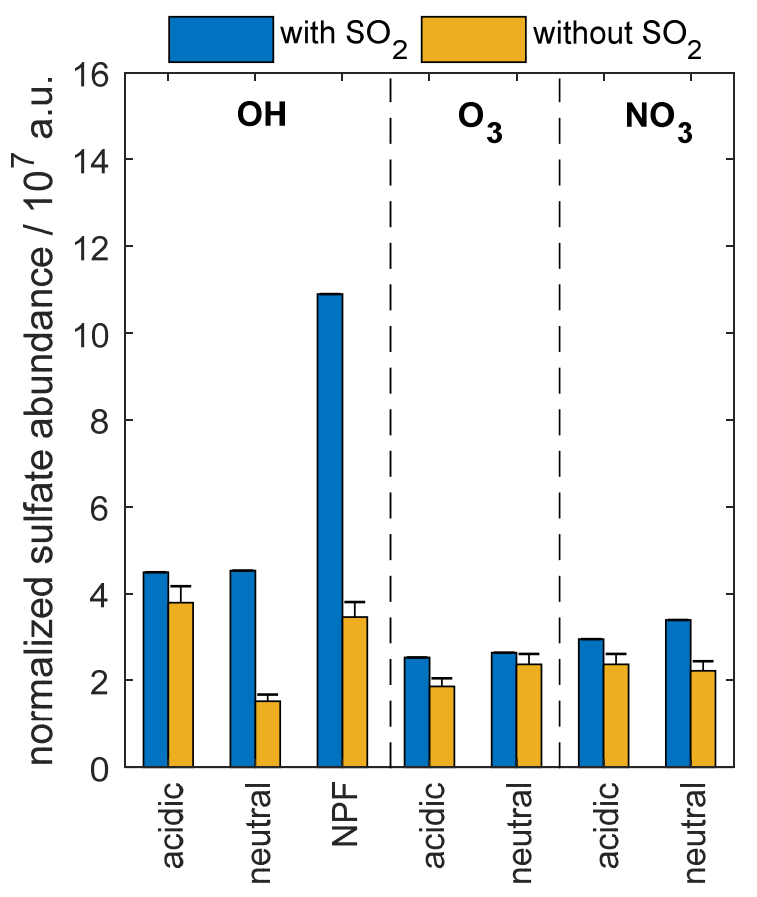

Figure S4. Detection of particulate sulfate from filter samples for various oxidants and seed particle acidities with and without $\mathrm{SO}_{2}$ removal through the denuder. Total peak areas of sulfate (detected as $\mathrm{HSO}_{4}{ }^{-}, \mathrm{m} / \mathrm{z}$ 96.9601) are normalized to the particle mass concentration during filter sampling. Error bars depict maximum denuder losses of up to $10 \%$. 

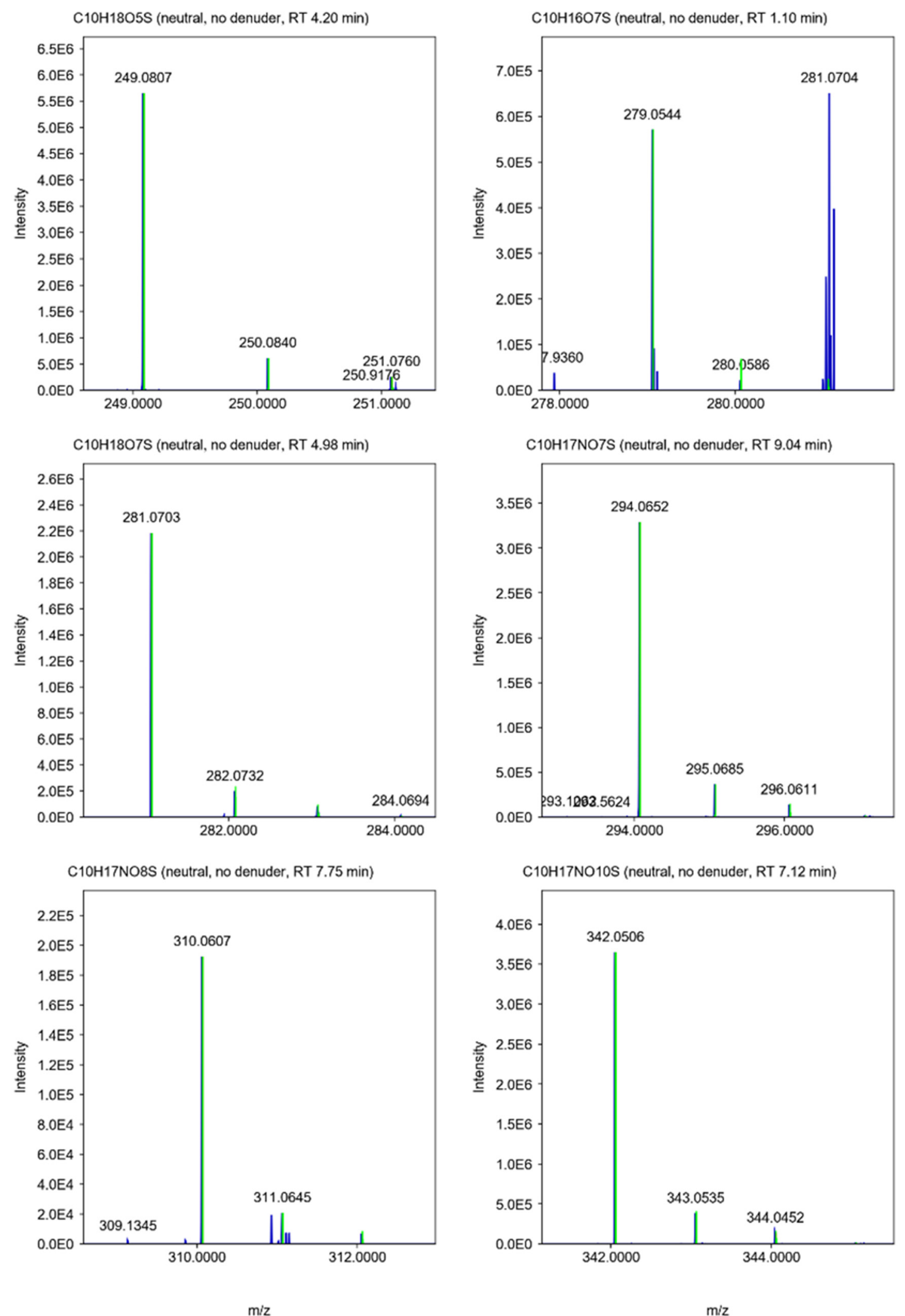

Figure S5. Predicted isotopic pattern (green) and observed ion signals (blue) from LC-MS measurements for common $\mathrm{OS}$ species detected in $\mathrm{OH}$ oxidation experiments. 

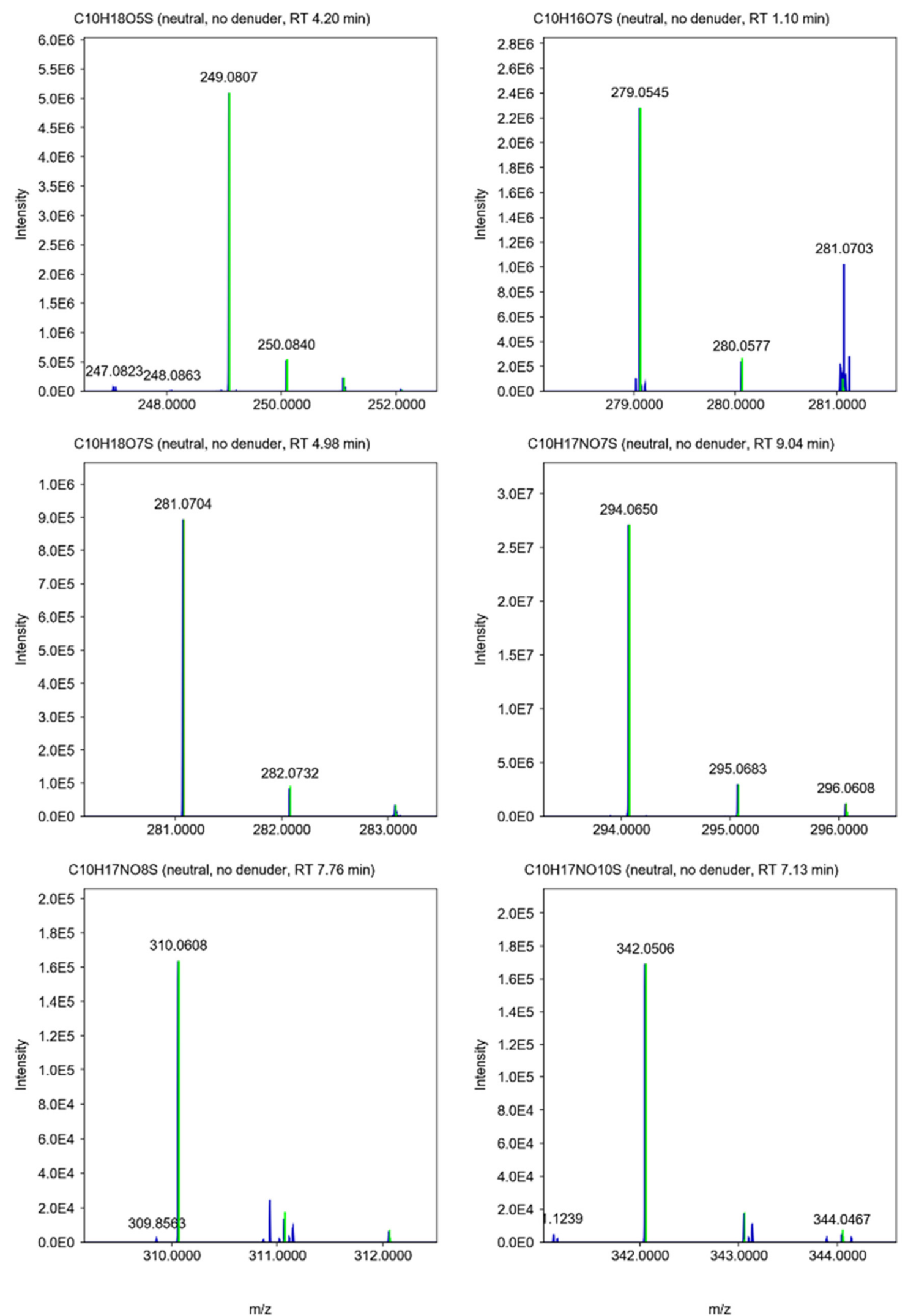

Figure S6. Predicted isotopic pattern (green) and observed ion signals (blue) from LC-MS measurements for common OS species detected in $\mathrm{O}_{3}$ oxidation experiments. 

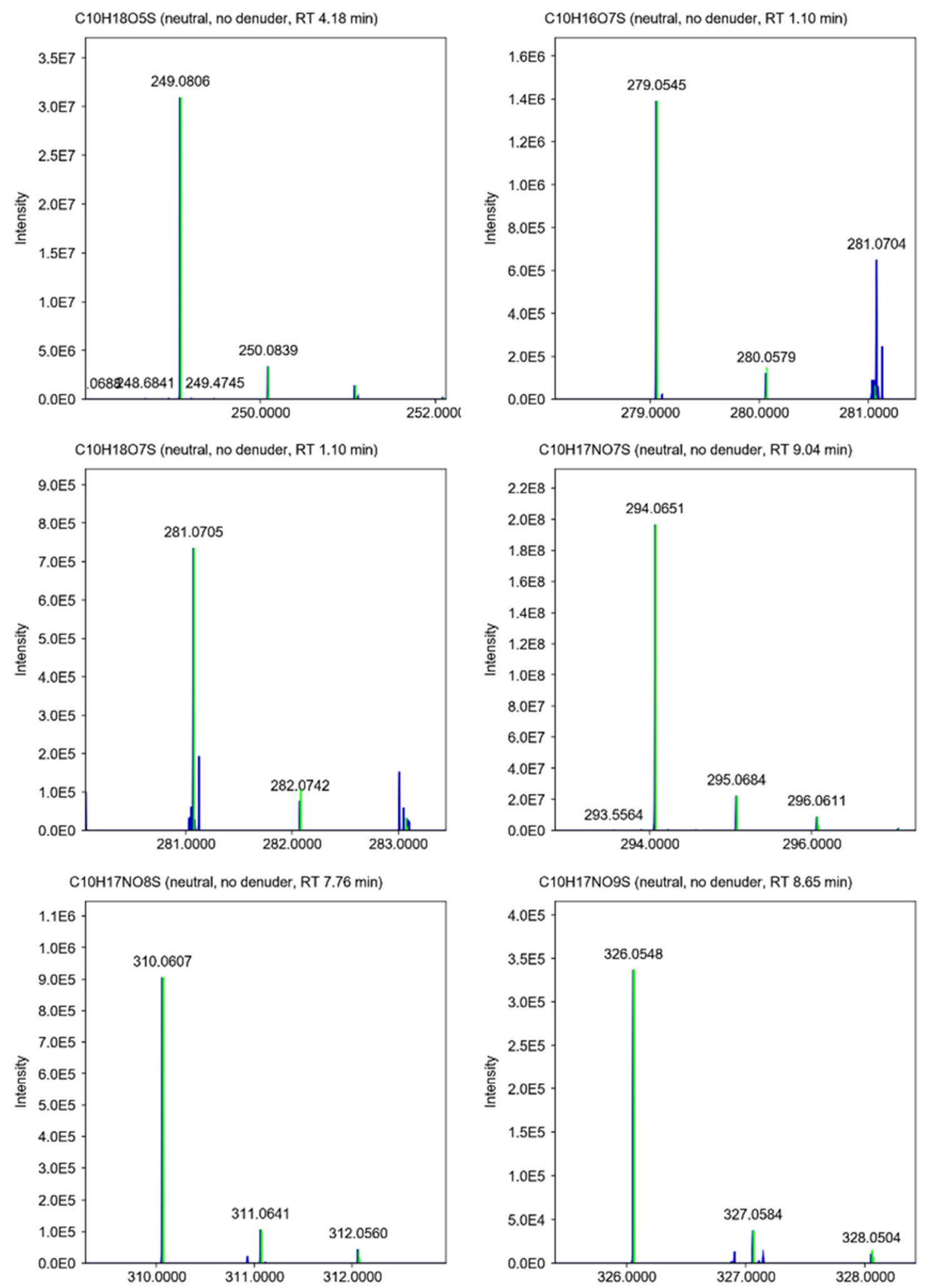

$\mathrm{m} / \mathrm{z}$

$\mathrm{m} / \mathrm{z}$

Figure S7. Predicted isotopic pattern (green) and observed ion signals (blue) from LC-MS measurements for common OS species detected in $\mathrm{NO}_{3}$ oxidation experiments. 

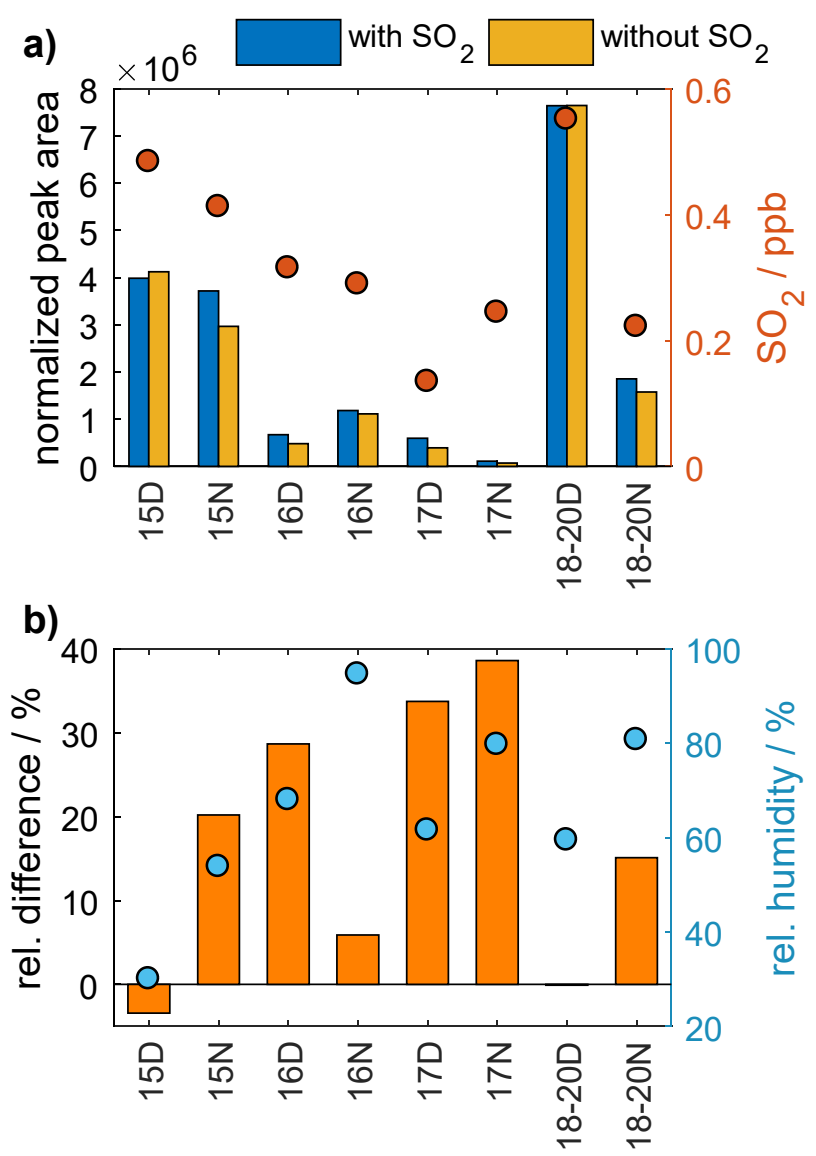

Figure S8. Detection of MT-OSs from PTFE filter samples with and without $\mathrm{SO}_{2}$ removal through the denuder during the field study (daytime and nighttime samples are indicated by " $\mathrm{D}$ " and " $\mathrm{N}$ ", respectively). Panel a) Abundance of detected OSs normalized to the average PM $_{2.5}$ mass during the sampling time. Panel b) Relative difference between the sample types in normalized OS abundances for each sampling period. Average values for $\mathrm{SO}_{2}$ levels and relative humidity are given on the second y-axes. 

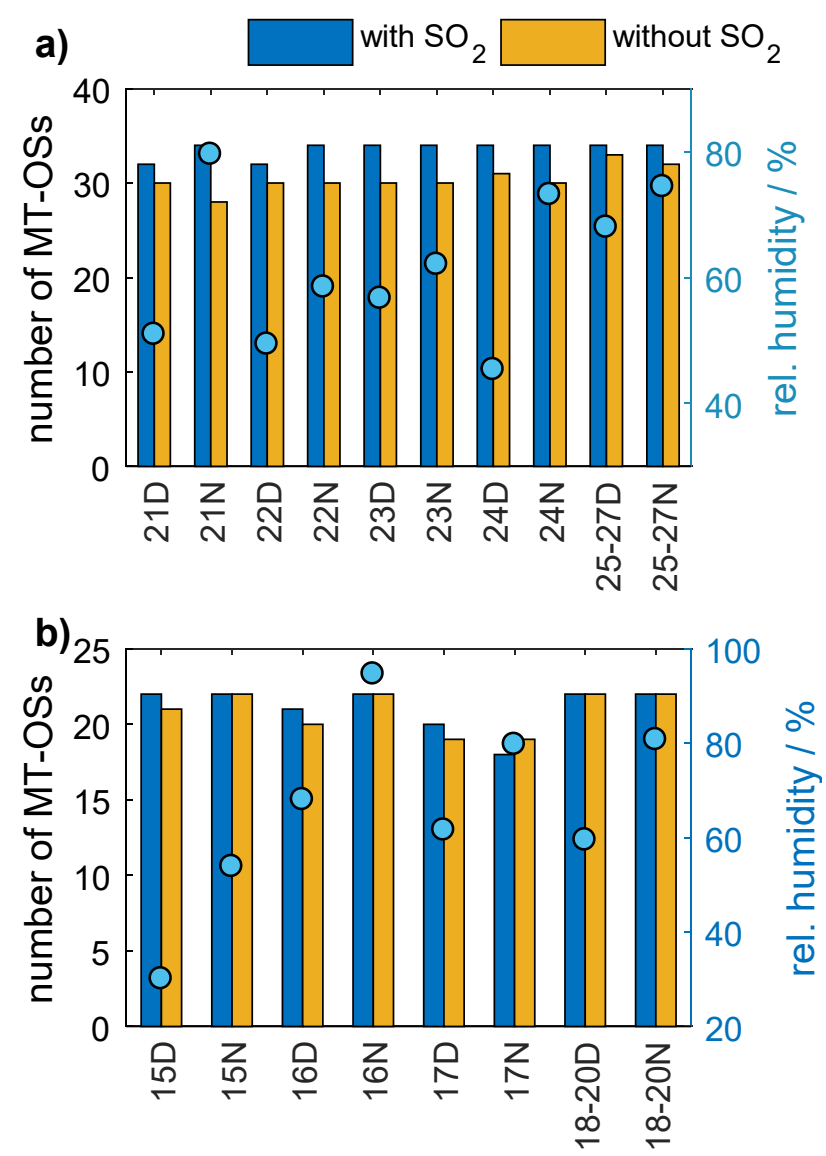

Figure S9. Number of detected MT-OSs from quartz (panel a) and PTFE (panel b) filter samples with and without $\mathrm{SO}_{2}$ removal through the denuder during the field study (daytime and nighttime samples are indicated by " $\mathrm{D}$ " and " $\mathrm{N}$ ", respectively).

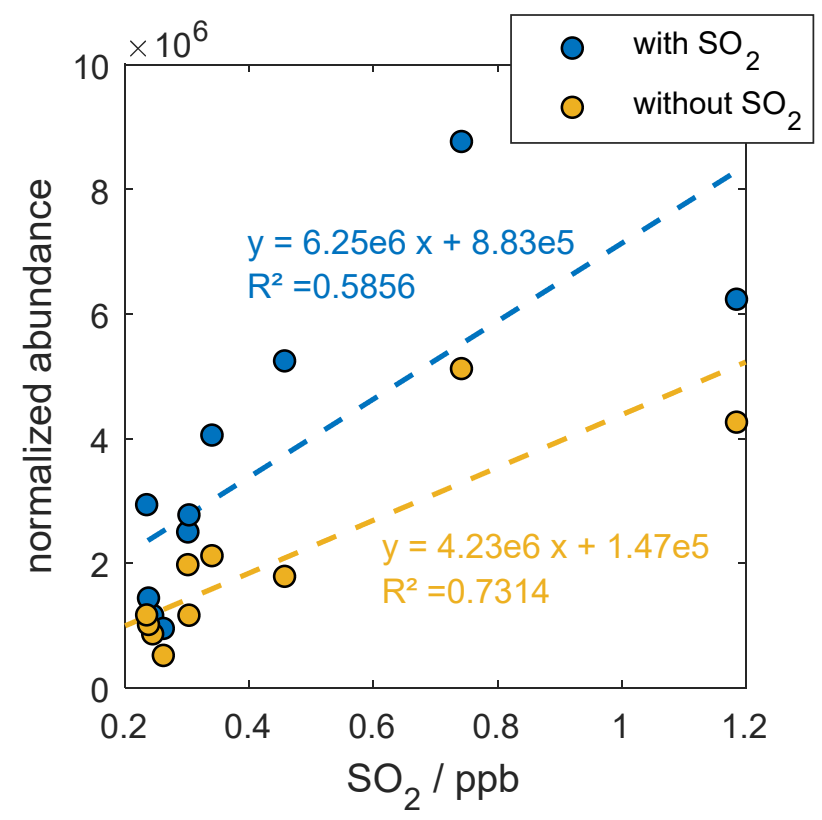

Figure S10. $\mathrm{PM}_{2.5}$-normalized abundance of MT-OSs for quartz filter samples as a function of $\mathrm{SO}_{2}$ levels (i.e., with and without $\mathrm{SO}_{2}$ removal). The dashed lines show linear regression fits for each sample type. 


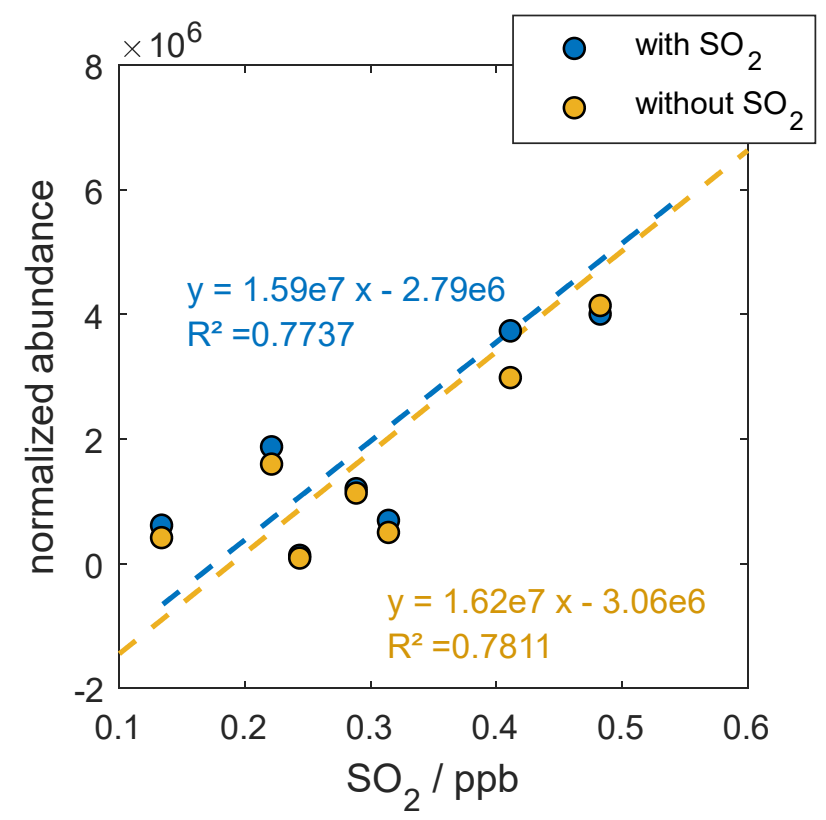

Figure S11. $\mathrm{PM}_{2.5}$-normalized abundance of MT-OSs for PTFE filter samples as a function of $\mathrm{SO}_{2}$ levels (i.e., with and without $\mathrm{SO}_{2}$ removal). The dashed lines show linear regression fits for each sample type.

a)

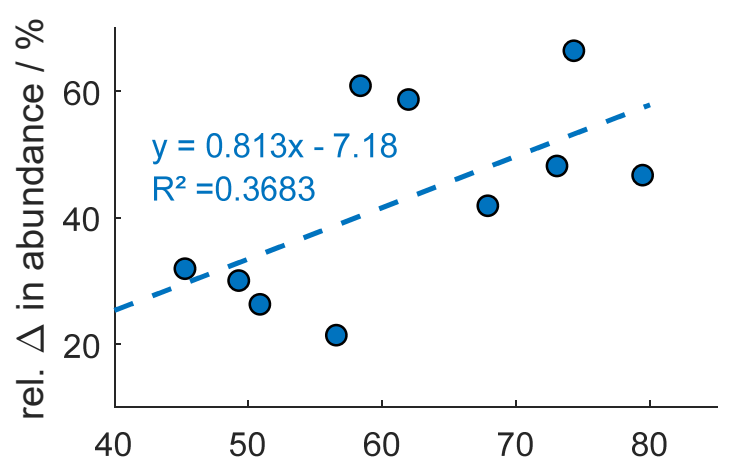

c)

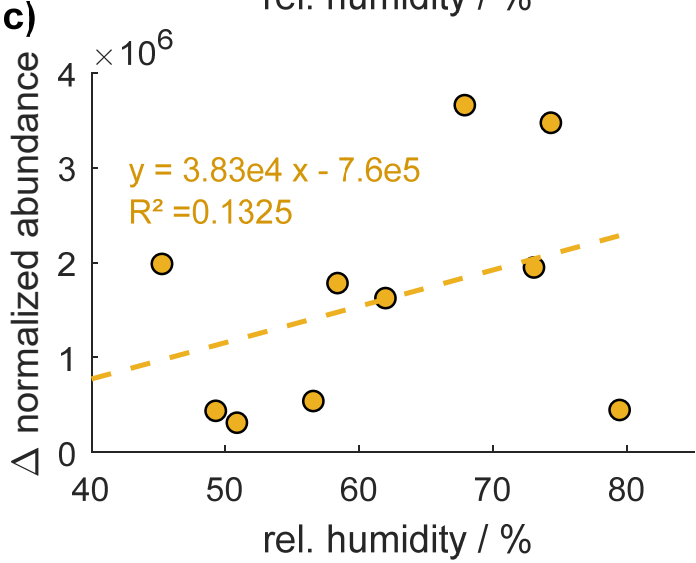

b)

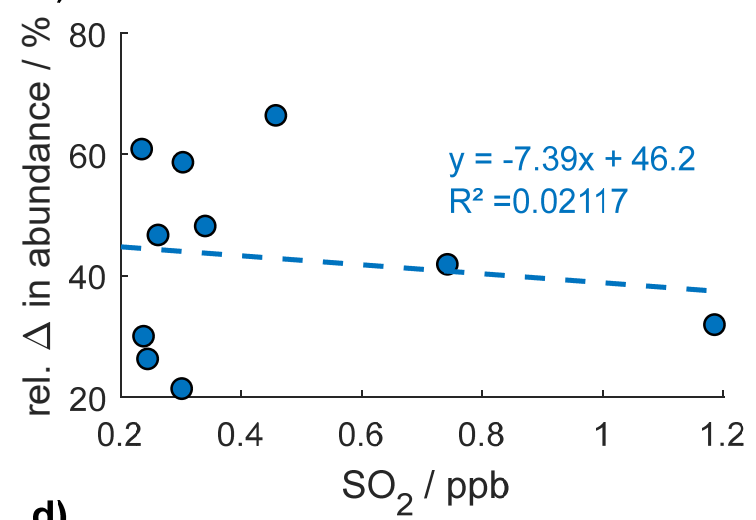

d)

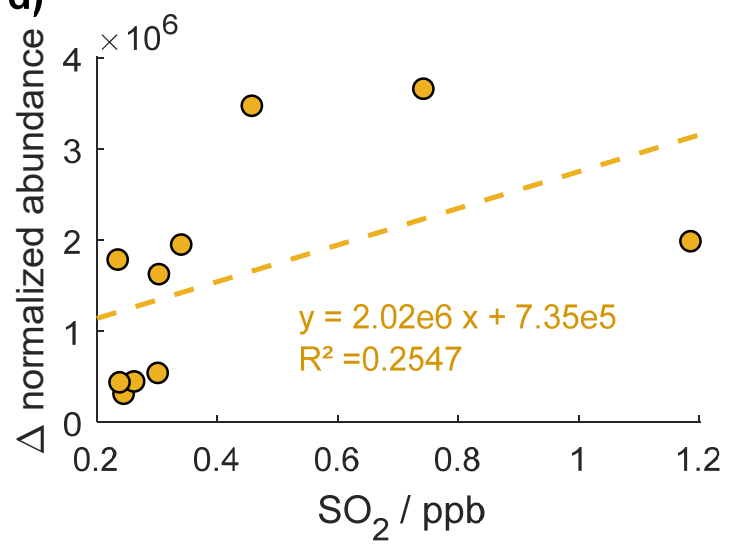

Figure S12. Correlation plots for quartz filter samples from the field study. Artifact formation as a function of relative humidity in relative (panel a) and absolute (panel c) differences of normalized MT-OS abundances. Artifact formation as a function of $\mathrm{SO}_{2}$ levels in relative (panel b) and absolute (panel d) differences of normalized MT-OS abundances. 
a)

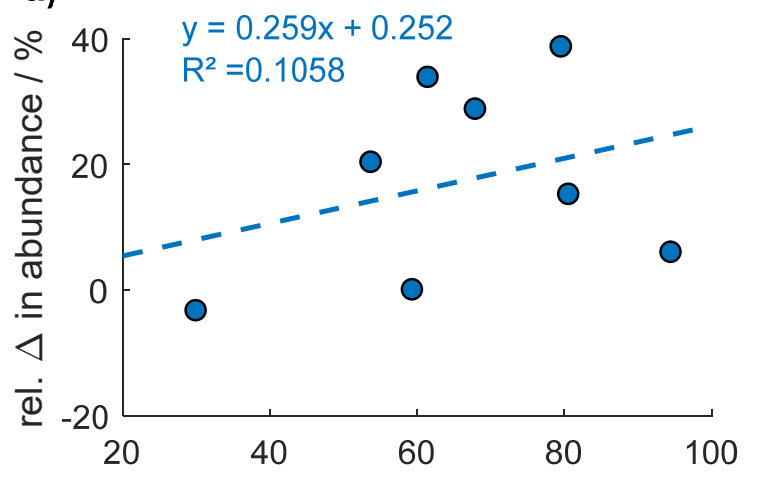

c)

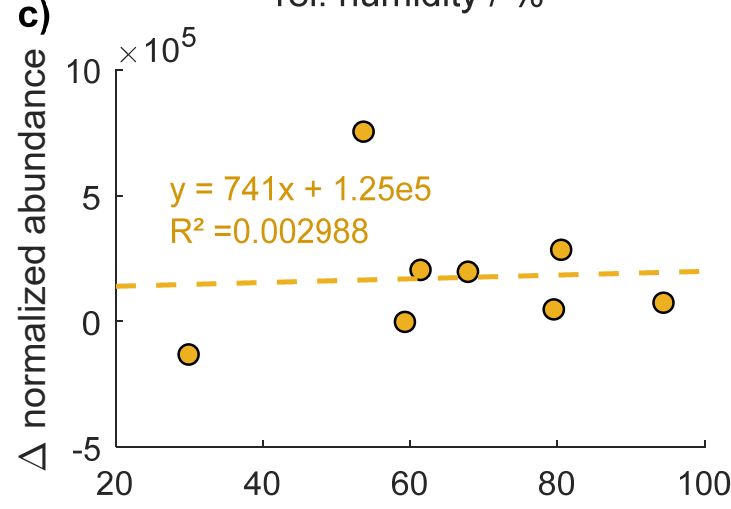

rel. humidity / \% b)
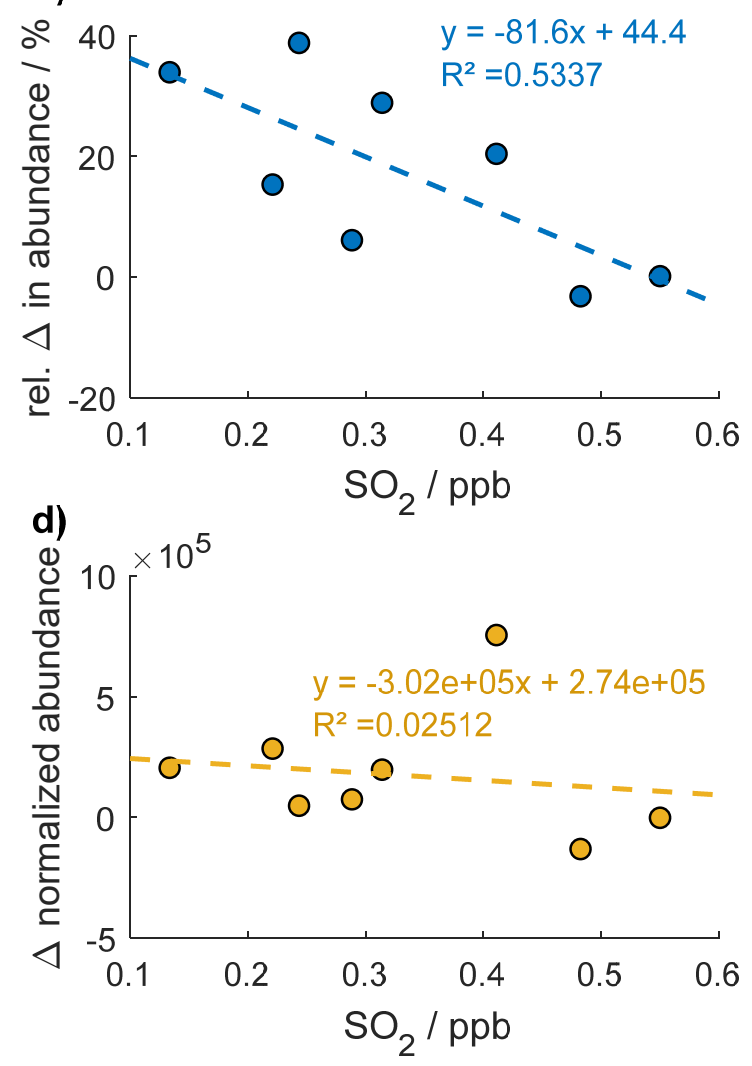

Figure S13. Correlation plots for PTFE filter samples from the field study. Artifact formation as a function of relative humidity in relative (panel a) and absolute (panel c) differences of normalized MT-OS abundances. Artifact formation as a function of $\mathrm{SO}_{2}$ levels in relative (panel b) and absolute (panel d) differences of normalized MT-OS abundances. 
Table S1. Overview on experimental conditions of the chamber runs and the corresponding filter samples analyzed by LC-MS.

\begin{tabular}{|c|c|c|c|c|c|c|c|c|c|}
\hline experiment & Oxidant & $\alpha$-pinene / ppb & RH / \% & Filter \# & Seed Acidity (pH) & SO2 removal & particle mass ${ }^{a} / \mu g^{3} m^{-3}$ & normalized peak area / a.u. & number of detected OSs \\
\hline 1 & $\mathrm{NO}_{3}$ & 60 & 50 & 1 & acidic (2) & no & 49.12 & $1.53 \mathrm{E}+07$ & 28 \\
\hline 1 & $\mathrm{NO}_{3}$ & 60 & 50 & 1 & acidic (2) & yes & 49.12 & $3.76 \mathrm{E}+04$ & 11 \\
\hline 2 & $\mathrm{NO}_{3}$ & 60 & 50 & 1 & neutral & no & 98.78 & $1.26 \mathrm{E}+07$ & 27 \\
\hline 2 & $\mathrm{NO}_{3}$ & 60 & 50 & 1 & neutral & yes & 98.78 & $3.42 \mathrm{E}+04$ & 10 \\
\hline 3 & $\mathrm{OH}$ & 60 & 50 & 1 & NPF & no & 14.8 & $1.94 \mathrm{E}+06$ & 27 \\
\hline 3 & $\mathrm{OH}$ & 60 & 50 & 1 & NPF & yes & 14.8 & $1.54 \mathrm{E}+05$ & 12 \\
\hline 4 & $\mathrm{NO}_{3}$ & 60 & 50 & 2 & acidic (2) & no & 54.1 & $3.51 E+07$ & 33 \\
\hline 4 & $\mathrm{NO}_{3}$ & 60 & 50 & 2 & acidic (2) & yes & 54.1 & $3.59 E+04$ & 11 \\
\hline 5 & $\mathrm{O}_{3}$ & 60 & 50 & 3 & acidic (1.2) & no & 67.66 & $3.75 \mathrm{E}+06$ & 22 \\
\hline 5 & $\mathrm{O}_{3}$ & 60 & 50 & 3 & acidic (1.2) & yes & 67.66 & $8.31 \mathrm{E}+04$ & 16 \\
\hline $6 a$ & $\mathrm{OH}$ & 60 & 50 & 2 & acidic (2) & no & 36.42 & $2.82 \mathrm{E}+06$ & 25 \\
\hline $6 b$ & $\mathrm{OH}$ & 60 & 50 & 3 & acidic (1.2) & no & 32.28 & $3.29 E+06$ & 28 \\
\hline $6 a$ & $\mathrm{OH}$ & 60 & 50 & 2 & acidic (2) & yes & 36.42 & $5.86 \mathrm{E}+04$ & 15 \\
\hline $6 b$ & $\mathrm{OH}$ & 60 & 50 & 3 & acidic (1.2) & yes & 32.28 & $1.99 E+05$ & 21 \\
\hline $7 a$ & $\mathrm{OH}$ & 60 & 50 & 2 & neutral & no & 37.96 & $2.31 \mathrm{E}+06$ & 28 \\
\hline $7 b$ & $\mathrm{OH}$ & 60 & 50 & 3 & neutral & no & 73.14 & $2.13 E+06$ & 26 \\
\hline $7 a$ & $\mathrm{OH}$ & 60 & 50 & 2 & neutral & yes & 37.96 & $4.84 \mathrm{E}+04$ & 9 \\
\hline $7 b$ & $\mathrm{OH}$ & 60 & 50 & 3 & neutral & yes & 73.14 & $7.61 E+04$ & 15 \\
\hline $8 a$ & $\mathrm{OH}$ & 60 & 50 & 2 & neutral & no & 111.08 & $3.01 E+06$ & 24 \\
\hline $8 b$ & $\mathrm{OH}$ & 100 & 50 & 3 & neutral & no & 165.78 & $2.73 E+06$ & 22 \\
\hline $8 a$ & $\mathrm{OH}$ & 60 & 50 & 2 & neutral & yes & 111.08 & $4.68 \mathrm{E}+04$ & 9 \\
\hline $8 b$ & $\mathrm{OH}$ & 100 & 50 & 3 & neutral & yes & 165.78 & $5.25 \mathrm{E}+04$ & 17 \\
\hline 9 & $\mathrm{NO}_{3}$ & 60 & 50 & 2 & neutral & no & 51.6 & $2.24 \mathrm{E}+07$ & 24 \\
\hline 9 & $\mathrm{NO}_{3}$ & 60 & 50 & 2 & neutral & yes & 51.6 & $1.30 \mathrm{E}+04$ & 8 \\
\hline $10 a$ & $\mathrm{OH}$ & 60 & 50 & 1 & NPF & no & 22.16 & $6.49 \mathrm{E}+06$ & 26 \\
\hline $10 \mathrm{~b}$ & $\mathrm{OH}$ & 100 & 50 & 2 & NPF & no & 41.76 & $3.51 \mathrm{E}+06$ & 25 \\
\hline $10 c$ & $\mathrm{OH}$ & 60 & 50 & 3 & acidic (1.2) & no & 154.02 & $9.82 E+05$ & 27 \\
\hline $10 d$ & $\mathrm{NO}_{3}$ & 60 & 50 & 4 & acidic (1.2) & no & 51.34 & $2.70 E+07$ & 29 \\
\hline $10 a$ & $\mathrm{OH}$ & 60 & 50 & 1 & NPF & yes & 22.16 & $6.05 E+04$ & 6 \\
\hline $10 \mathrm{~b}$ & $\mathrm{OH}$ & 100 & 50 & 2 & NPF & yes & 41.76 & $2.82 E+04$ & 5 \\
\hline $10 c$ & $\mathrm{OH}$ & 60 & 50 & 3 & acidic (1.2) & yes & 154.02 & $5.94 \mathrm{E}+04$ & 9 \\
\hline $10 d$ & $\mathrm{NO}_{3}$ & 60 & 50 & 4 & acidic (1.2) & yes & 51.34 & $8.54 \mathrm{E}+04$ & 9 \\
\hline 11a & $\mathrm{NO}_{3}$ & 100 & 50 & 2 & acidic (1.2) & no & 72.44 & $2.50 \mathrm{E}+07$ & 32 \\
\hline $11 b$ & $\mathrm{OH}$ & 60 & 50 & 3 & acidic (1.2) & no & 77.2 & $6.92 \mathrm{E}+05$ & 26 \\
\hline $11 \mathrm{c}$ & $\mathrm{OH}$ & 60 & 50 & 4 & acidic (1.2) & no & 78.5 & $3.25 \mathrm{E}+06$ & 35 \\
\hline $11 a$ & $\mathrm{NO}_{3}$ & 100 & 50 & 2 & acidic (1.2) & yes & 72.44 & $1.02 \mathrm{E}+05$ & 14 \\
\hline $11 \mathrm{~b}$ & $\mathrm{OH}$ & 60 & 50 & 3 & acidic (1.2) & yes & 77.2 & $1.42 \mathrm{E}+05$ & 16 \\
\hline $11 \mathrm{c}$ & $\mathrm{OH}$ & 60 & 50 & 4 & acidic (1.2) & yes & 78.5 & 1.29E+05 & 23 \\
\hline 12 & $\mathrm{O}_{3}$ & 60 & 50 & 3 & neutral & no & 58.24 & $6.00 \mathrm{E}+06$ & 23 \\
\hline 12 & $\mathrm{O}_{3}$ & 60 & 50 & 3 & neutral & yes & 58.24 & $1.85 \mathrm{E}+04$ & 8 \\
\hline
\end{tabular}

a assuming an average particle density of $2 \mathrm{~g} \mathrm{~cm}^{-3}$ 
Table S2. LC-MS enhancement factors for particle mass-normalized peak areas of single OS species in the presence of $15 \mathrm{ppb} \mathrm{SO}{ }_{2}$ during filter sampling. OSs that were only detectable in presence of $\mathrm{SO}_{2}$ are denoted with "+".

\begin{tabular}{|c|c|c|c|c|c|c|c|}
\hline Oxidant & \multicolumn{3}{|c|}{$\mathrm{OH}$} & \multicolumn{2}{|c|}{$\mathrm{O}_{3}$} & \multicolumn{2}{|c|}{$\mathrm{NO}_{3}$} \\
\hline ula & $\frac{\underline{y}}{\frac{0}{0}}$ & 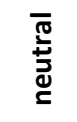 & $\frac{u}{2}$ & 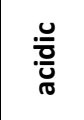 & 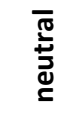 & $\frac{.0}{0}$ & 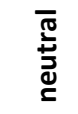 \\
\hline $\mathrm{C}_{10} \mathrm{H}_{18} \mathrm{O}_{5} \mathrm{~S}$ & 7.95 & 602 & 495 & 31.0 & + & 10.2 & + \\
\hline $\mathrm{C}_{10} \mathrm{H}_{16} \mathrm{O}_{7} \mathrm{~S}$ & 7.08 & + & 23.4 & 8.07 & 51.7 & 25.3 & + \\
\hline $\mathrm{C}_{10} \mathrm{H}_{18} \mathrm{O}_{7} \mathrm{~S}$ & 39.7 & 37.9 & 79.7 & 30.2 & 136 & 32.0 & + \\
\hline $\mathrm{C}_{10} \mathrm{H}_{17} \mathrm{NO}_{7} \mathrm{~S}$ & 115 & 471 & 1400 & 1535 & 4930 & 1923 & 1880 \\
\hline $\mathrm{C}_{8} \mathrm{H}_{14} \mathrm{O}_{10} \mathrm{~S}$ & 1.64 & 1.73 & 2.42 & 1.44 & 1.60 & 2.44 & 3.09 \\
\hline $\mathrm{C}_{10} \mathrm{H}_{17} \mathrm{NO}_{8} \mathrm{~S}$ & 5.57 & 102 & + & + & + & 48.1 & 76.6 \\
\hline $\mathrm{C}_{10} \mathrm{H}_{17} \mathrm{NO}_{9} \mathrm{~S}$ & + & + & + & + & + & + & 92.3 \\
\hline $\mathrm{C}_{10} \mathrm{H}_{17} \mathrm{NO}_{10} \mathrm{~S}$ & 45.9 & 33.8 & 32.0 & + & + & 23.6 & 11.6 \\
\hline $\mathrm{C}_{10} \mathrm{H}_{22} \mathrm{O}_{13} \mathrm{~S}$ & 3.69 & 1.00 & + & + & + & + & + \\
\hline $\mathrm{C}_{18} \mathrm{H}_{37} \mathrm{NO}_{7} \mathrm{~S}$ & + & + & + & + & + & + & + \\
\hline $\mathrm{C}_{20} \mathrm{H}_{32} \mathrm{O}_{8} \mathrm{~S}$ & + & + & + & + & + & + & + \\
\hline $\mathrm{C}_{19} \mathrm{H}_{38} \mathrm{O}_{7} \mathrm{~S}_{2}$ & 23.2 & 0.95 & + & + & + & + & + \\
\hline $\mathrm{C}_{19} \mathrm{H}_{31} \mathrm{NO}_{10} \mathrm{~S}$ & + & + & + & + & + & + & + \\
\hline $\mathrm{C}_{22} \mathrm{H}_{40} \mathrm{O}_{11} \mathrm{~S}$ & + & + & + & + & + & + & + \\
\hline
\end{tabular}


Table S3. Comparison of direct infusion-ESI-MS and LC-ESI-MS on the number of detected of OSs in filter extracts from the chamber experiments.

\begin{tabular}{|c|c|c|c|c|}
\hline$m / z$ & molecular formula & direct infusion-ESI-MS & LC-ESI-MS & EESI-MS \\
\hline 140.9862 & $\mathrm{C}_{2} \mathrm{H}_{6} \mathrm{O}_{5} \mathrm{~S}$ & detected & - & detected \\
\hline 152.9863 & $\mathrm{C}_{3} \mathrm{H}_{6} \mathrm{O}_{5} \mathrm{~S}$ & detected & - & - \\
\hline 179.0021 & $\mathrm{C}_{5} \mathrm{H}_{8} \mathrm{O}_{5} \mathrm{~S}$ & detected & - & - \\
\hline 205.0541 & $\mathrm{C}_{8} \mathrm{H}_{14} \mathrm{O}_{4} \mathrm{~S}$ & detected & - & - \\
\hline 219.0696 & $\mathrm{C}_{9} \mathrm{H}_{16} \mathrm{O}_{4} \mathrm{~S}$ & detected & - & - \\
\hline 223.0281 & $\mathrm{C}_{7} \mathrm{H}_{12} \mathrm{O}_{6} \mathrm{~S}$ & detected & - & - \\
\hline 235.0647 & $\mathrm{C}_{9} \mathrm{H}_{16} \mathrm{O}_{5} \mathrm{~S}$ & detected & - & detected \\
\hline 239.0235 & $\mathrm{C}_{7} \mathrm{H}_{12} \mathrm{O}_{7} \mathrm{~S}$ & detected & - & - \\
\hline 245.0486 & $\mathrm{C}_{10} \mathrm{H}_{14} \mathrm{O}_{5} \mathrm{~S}$ & detected & - & - \\
\hline 247.0647 & $\mathrm{C}_{10} \mathrm{H}_{16} \mathrm{O}_{5} \mathrm{~S}$ & detected & - & - \\
\hline 249.0806 & $\mathrm{C}_{10} \mathrm{H}_{18} \mathrm{O}_{5} \mathrm{~S}$ & detected & detected & detected \\
\hline 263.0596 & $\mathrm{C}_{10} \mathrm{H}_{16} \mathrm{O}_{6} \mathrm{~S}$ & detected & - & - \\
\hline 265.0748 & $\mathrm{C}_{10} \mathrm{H}_{18} \mathrm{O}_{6} \mathrm{~S}$ & detected & - & - \\
\hline 267.0545 & $\mathrm{C}_{9} \mathrm{H}_{16} \mathrm{O}_{7} \mathrm{~S}$ & detected & - & detected \\
\hline 279.0544 & $\mathrm{C}_{10} \mathrm{H}_{16} \mathrm{O}_{7} \mathrm{~S}$ & detected & detected & detected \\
\hline 279.0910 & $\mathrm{C}_{11} \mathrm{H}_{20} \mathrm{O}_{6} \mathrm{~S}$ & detected & - & detected \\
\hline 281.0703 & $\mathrm{C}_{10} \mathrm{H}_{18} \mathrm{O}_{7} \mathrm{~S}$ & detected & detected & detected \\
\hline 289.0752 & $\mathrm{C}_{12} \mathrm{H}_{18} \mathrm{O}_{6} \mathrm{~S}$ & detected & - & - \\
\hline 294.0649 & $\mathrm{C}_{10} \mathrm{H}_{17} \mathrm{NO}_{7} \mathrm{~S}$ & detected & detected & detected \\
\hline 297.0646 & $\mathrm{C}_{10} \mathrm{H}_{18} \mathrm{O}_{8} \mathrm{~S}$ & detected & - & - \\
\hline 301.0240 & $\mathrm{C}_{8} \mathrm{H}_{14} \mathrm{O}_{10} \mathrm{~S}$ & - & detected & - \\
\hline 310.0607 & $\mathrm{C}_{10} \mathrm{H}_{17} \mathrm{NO}_{8} \mathrm{~S}$ & - & detected & - \\
\hline 326.0553 & $\mathrm{C}_{10} \mathrm{H}_{17} \mathrm{NO}_{9} \mathrm{~S}$ & - & detected & - \\
\hline 339.1663 & $\mathrm{C}_{15} \mathrm{H}_{32} \mathrm{O}_{4} \mathrm{~S}_{2}$ & detected & - & - \\
\hline 342.0503 & $\mathrm{C}_{10} \mathrm{H}_{17} \mathrm{NO}_{10} \mathrm{~S}$ & detected & detected & - \\
\hline 381.0712 & $\mathrm{C}_{10} \mathrm{H}_{22} \mathrm{O}_{13} \mathrm{~S}$ & - & detected & - \\
\hline 383.1927 & $\mathrm{C}_{17} \mathrm{H}_{36} \mathrm{O}_{5} \mathrm{~S}_{2}$ & detected & - & detected \\
\hline 392.2113 & $\mathrm{C}_{18} \mathrm{H}_{35} \mathrm{NO}_{6} \mathrm{~S}$ & detected & - & - \\
\hline 410.2226 & $\mathrm{C}_{18} \mathrm{H}_{37} \mathrm{NO}_{7} \mathrm{~S}$ & detected & detected & - \\
\hline 427.2184 & $\mathrm{C}_{19} \mathrm{H}_{40} \mathrm{O}_{6} \mathrm{~S}_{2}$ & detected & - & - \\
\hline 431.1741 & $\mathrm{C}_{20} \mathrm{H}_{32} \mathrm{O}_{8} \mathrm{~S}$ & - & detected & - \\
\hline 441.1981 & $\mathrm{C}_{19} \mathrm{H}_{38} \mathrm{O}_{7} \mathrm{~S}_{2}$ & - & detected & - \\
\hline 463.1861 & $\mathrm{C}_{17} \mathrm{H}_{36} \mathrm{O}_{12} \mathrm{~S}$ & detected & - & - \\
\hline 464.1603 & $\mathrm{C}_{19} \mathrm{H}_{31} \mathrm{NO}_{10} \mathrm{~S}$ & - & detected & - \\
\hline 511.2221 & $\mathrm{C}_{22} \mathrm{H}_{40} \mathrm{O}_{11} \mathrm{~S}$ & - & detected & - \\
\hline total number & 35 & 27 & 14 & 9 \\
\hline
\end{tabular}

Table S4. OS signals displayed in Figure $2 \mathrm{a}$, which were increasing upon removal of the charcoal denuder during $\mathrm{OH}$ oxidation of $\alpha$-pinene in the presence of $\mathrm{NO}_{x}$ and $\mathrm{SO}_{2}$.

\begin{tabular}{cc}
\hline $\boldsymbol{m} / \boldsymbol{z}$ & molecular formula \\
\hline 138.9708 & $\mathrm{C}_{2} \mathrm{H}_{4} \mathrm{O}_{5} \mathrm{~S}$ \\
219.0334 & $\mathrm{C}_{8} \mathrm{H}_{12} \mathrm{O}_{5} \mathrm{~S}$ \\
223.0284 & $\mathrm{C}_{7} \mathrm{H}_{12} \mathrm{O}_{6} \mathrm{~S}$ \\
235.0283 & $\mathrm{C}_{8} \mathrm{H}_{12} \mathrm{O}_{6} \mathrm{~S}$ \\
237.0075 & $\mathrm{C}_{7} \mathrm{H}_{10} \mathrm{O}_{7} \mathrm{~S}$ \\
239.0598 & $\mathrm{C}_{8} \mathrm{H}_{16} \mathrm{O}_{6} \mathrm{~S}$ \\
249.0439 & $\mathrm{C}_{9} \mathrm{H}_{14} \mathrm{O}_{6} \mathrm{~S}$ \\
263.0236 & $\mathrm{C}_{9} \mathrm{H}_{12} \mathrm{O}_{7} \mathrm{~S}$ \\
263.0597 & $\mathrm{C}_{10} \mathrm{H}_{16} \mathrm{O}_{6} \mathrm{~S}$ \\
277.1122 & $\mathrm{C}_{12} \mathrm{H}_{22} \mathrm{O}_{5} \mathrm{~S}$ \\
281.0336 & $\mathrm{C}_{9} \mathrm{H}_{14} \mathrm{O}_{8} \mathrm{~S}$ \\
282.0288 & $\mathrm{C}_{8} \mathrm{H}_{13} \mathrm{NO}_{8} \mathrm{~S}$ \\
295.0492 & $\mathrm{C}_{10} \mathrm{H}_{16} \mathrm{O}_{8} \mathrm{~S}$ \\
309.0656 & $\mathrm{C}_{11} \mathrm{H}_{18} \mathrm{O}_{8} \mathrm{~S}$ \\
\hline
\end{tabular}


Table S5. OS signals displayed in Figure $2 b$, which were increasing upon removal of the charcoal denuder during the ozonolysis of $\alpha$-pinene in the presence of $\mathrm{NO}_{x}$ and $\mathrm{SO}_{2}$.

\begin{tabular}{cc}
\hline $\boldsymbol{m} / \boldsymbol{z}$ & molecular formula \\
\hline 138.9708 & $\mathrm{C}_{2} \mathrm{H}_{4} \mathrm{O}_{5} \mathrm{~S}$ \\
233.0490 & $\mathrm{C}_{9} \mathrm{H}_{14} \mathrm{O}_{5} \mathrm{~S}$ \\
247.0647 & $\mathrm{C}_{10} \mathrm{H}_{16} \mathrm{O}_{5} \mathrm{~S}$ \\
249.0441 & $\mathrm{C}_{9} \mathrm{H}_{14} \mathrm{O}_{6} \mathrm{~S}$ \\
249.0805 & $\mathrm{C}_{10} \mathrm{H}_{18} \mathrm{O}_{5} \mathrm{~S}$ \\
263.0598 & $\mathrm{C}_{10} \mathrm{H}_{16} \mathrm{O}_{6} \mathrm{~S}$ \\
\hline
\end{tabular}

Table S6. OS signals displayed in Figure 2c, which were increasing upon removal of the charcoal denuder during $\mathrm{NO}_{3}$ oxidation of $\alpha$-pinene in the presence of $\mathrm{SO}_{2}$.

\begin{tabular}{cc}
\hline $\boldsymbol{m} / \boldsymbol{z}$ & molecular formula \\
\hline 138.9708 & $\mathrm{C}_{2} \mathrm{H}_{4} \mathrm{O}_{5} \mathrm{~S}$ \\
223.0283 & $\mathrm{C}_{7} \mathrm{H}_{12} \mathrm{O}_{6} \mathrm{~S}$ \\
233.0854 & $\mathrm{C}_{10} \mathrm{H}_{18} \mathrm{O}_{4} \mathrm{~S}$ \\
235.0284 & $\mathrm{C}_{8} \mathrm{H}_{12} \mathrm{O}_{6} \mathrm{~S}$ \\
239.0598 & $\mathrm{C}_{8} \mathrm{H}_{16} \mathrm{O}_{6} \mathrm{~S}$ \\
247.0650 & $\mathrm{C}_{10} \mathrm{H}_{16} \mathrm{O}_{5} \mathrm{~S}$ \\
249.0439 & $\mathrm{C}_{9} \mathrm{H}_{14} \mathrm{O}_{6} \mathrm{~S}$ \\
249.0805 & $\mathrm{C}_{10} \mathrm{H}_{18} \mathrm{O}_{5} \mathrm{~S}$ \\
263.0598 & $\mathrm{C}_{10} \mathrm{H}_{16} \mathrm{O}_{6} \mathrm{~S}$ \\
294.0653 & $\mathrm{C}_{10} \mathrm{H}_{17} \mathrm{NO}_{7} \mathrm{~S}$ \\
368.0662 & $\mathrm{C}_{12} \mathrm{H}_{19} \mathrm{NO}_{10} \mathrm{~S}$ \\
\hline
\end{tabular}

Table S7. Overview on average values for meteorological parameters, $\mathrm{PM}_{2.5}$ mass concentrations, trace gas levels, and total $\mathrm{SO}_{2}$ exposure of the samples during the filter sampling periods at the Melpitz field station. For comparison, total $\mathrm{SO}_{2}$ exposure of chamber samples was $21.55 \mu \mathrm{g}$.

\begin{tabular}{|c|c|c|c|c|c|c|c|c|c|c|}
\hline $\begin{array}{l}\text { sample } \\
\text { name }\end{array}$ & $\begin{array}{l}\text { filter } \\
\text { material }\end{array}$ & $\begin{array}{l}\mathrm{PM}_{2.5} / \\
\mu \mathrm{g} \mathrm{m}^{-3}\end{array}$ & $\begin{array}{l}\mathrm{SO}_{2} / \\
\mathrm{ppb}\end{array}$ & $\begin{array}{l}\mathrm{O}_{3} / \\
\mathrm{ppb}\end{array}$ & $\begin{array}{l}\text { NO / } \\
\text { ppb }\end{array}$ & $\begin{array}{l}\mathrm{NO}_{2} / \\
\mathrm{ppb}\end{array}$ & $\mathrm{T} /{ }^{\circ} \mathrm{C}$ & $\begin{array}{l}\text { RH / } \\
\%\end{array}$ & $\begin{array}{l}\text { radiation } \\
/ \mathrm{W} \mathrm{m}^{-2}\end{array}$ & $\begin{array}{l}\text { Total } \mathrm{SO}_{2} \\
\text { exposure / } \\
\mu \mathrm{g}\end{array}$ \\
\hline $15 \mathrm{D}$ & PTFE & 1.94 & 0.48 & 57.42 & 0 & 0.15 & 27.15 & 30.05 & 415.61 & 2.98 \\
\hline $15 \mathrm{~N}$ & PTFE & 5.96 & 0.41 & 39.84 & 0 & 2.08 & 20.34 & 53.83 & 13.36 & 4.13 \\
\hline $16 \mathrm{D}$ & PTFE & 6.25 & 0.32 & 30.82 & 0.7 & 1.27 & 18.44 & 68.01 & 535.3 & 3.24 \\
\hline $16 \mathrm{~N}$ & PTFE & 12.82 & 0.29 & 20.54 & 0.08 & 2.81 & 15.08 & 94.59 & 10.14 & 3.00 \\
\hline 17D & PTFE & 3.19 & 0.13 & 32.66 & n.a. & n.a. & 18.92 & 61.57 & 382.32 & 1.37 \\
\hline $17 \mathrm{~N}$ & PTFE & 12.09 & 0.24 & 13.63 & n.a. & n.a. & 14.77 & 79.69 & 4.62 & 2.52 \\
\hline $18-20 D$ & PTFE & 9.64 & 0.55 & 44.71 & 0.24 & 1.23 & 23.75 & 59.45 & 588.78 & 5.53 \\
\hline $18-20 \mathrm{~N}$ & PTFE & 28.36 & 0.22 & 21.06 & n.a. & n.a. & 18.04 & 80.69 & 8.14 & 2.26 \\
\hline 21D & quartz & 3.2 & 0.25 & 34.14 & 0.08 & 0.2 & 20.01 & 50.96 & 679.84 & 2.54 \\
\hline $21 \mathrm{~N}$ & quartz & 5.31 & 0.26 & 15.91 & 0.21 & 3.09 & 16.15 & 79.54 & 15.41 & 2.74 \\
\hline $22 \mathrm{D}$ & quartz & 2.08 & 0.24 & 35.1 & 0.16 & 0.29 & 19.46 & 49.37 & 577.97 & 2.45 \\
\hline $22 \mathrm{~N}$ & quartz & 3.5 & 0.24 & 24.73 & 0 & 1.8 & 15.27 & 58.47 & 12.87 & 2.45 \\
\hline $23 \mathrm{D}$ & quartz & 2.99 & 0.3 & 38.31 & 0.09 & 0.59 & 18.99 & 56.66 & 436.9 & 3.10 \\
\hline $23 N$ & quartz & 6.08 & 0.3 & 25.53 & 0 & 2.5 & 16.01 & 62.05 & 17.38 & 3.14 \\
\hline $24 \mathrm{D}$ & quartz & 4.13 & 1.19 & 47.74 & 0.34 & 1.56 & 23.8 & 45.36 & 555.55 & 11.86 \\
\hline $24 N$ & quartz & 4.29 & 0.34 & 23.84 & 0 & 1.8 & 13.92 & 73.14 & 15.15 & 3.55 \\
\hline 25-27D & quartz & 5.95 & 0.74 & 35.12 & 0.52 & 1.33 & 21.8 & 67.97 & 441.05 & 7.49 \\
\hline $25-27 \mathrm{~N}$ & quartz & 14.34 & 0.46 & 24.66 & 0.67 & 3.43 & 18.25 & 74.41 & 10.16 & 4.66 \\
\hline
\end{tabular}




\section{References}

(1) Mutzel, A.; Poulain, L.; Berndt, T.; linuma, Y.; Rodigast, M.; Böge, O.; Richters, S.; Spindler, G.; Sipilä, M.; Jokinen, T.; Kulmala, M.; Herrmann, H. Highly Oxidized Multifunctional Organic Compounds Observed in Tropospheric Particles: A Field and Laboratory Study. Environmental Science \& Technology 2015, 49 (13), 7754-7761. https://doi.org/10.1021/acs.est.5b00885.

(2) Jayne, J. T.; Davidovits, P.; Worsnop, D. R.; Zahniser, M. S.; Kolb, C. E. Uptake of Sulfur Dioxide(G) by Aqueous Surfaces as a Function of PH: The Effect of Chemical Reaction at the Interface. $J$. Phys. Chem. 1990, 94 (15), 6041-6048. https://doi.org/10.1021/j100378a076.

(3) Kristensen, K.; Bilde, M.; Aalto, P. P.; Petäjä, T.; Glasius, M. Denuder/Filter Sampling of Organic Acids and Organosulfates at Urban and Boreal Forest Sites: Gas/Particle Distribution and Possible Sampling Artifacts. Atmospheric Environment 2016, 130, 36-53. https://doi.org/10.1016/J.ATMOSENV.2015.10.046.

(4) Wolfe, G. M.; Marvin, M. R.; Roberts, S. J.; Travis, K. R.; Liao, J. The Framework for 0-D Atmospheric Modeling (FOAM) v3.1. Geoscientific Model Development 2016, 9 (9), 3309-3319. https://doi.org/10.5194/gmd-9-3309-2016.

(5) Brauer, M.; Koutrakis, P.; Wolfson, J. M.; Spengler, J. D. Evaluation of the Gas Collection of an Annular Denuder System under Simulated Atmospheric Conditions. Atmospheric Environment (1967) 1989, 23 (9), 1981-1986. https://doi.org/10.1016/0004-6981(89)90524-6.

(6) Spindler, G.; Grüner, A.; Müller, K.; Schlimper, S.; Herrmann, H. Long-Term Size-Segregated Particle (PM10, PM2.5, PM1) Characterization Study at Melpitz -- Influence of Air Mass Inflow, Weather Conditions and Season. Journal of Atmospheric Chemistry 2013, 70 (2), 165-195. https://doi.org/10.1007/s10874-013-9263-8.

(7) Brüggemann, M.; Xu, R.; Tilgner, A.; Kwong, K. C.; Mutzel, A.; Poon, H. Y.; Otto, T.; Schaefer, T.; Poulain, L.; Chan, M. N.; Herrmann, H. Organosulfates in Ambient Aerosol: State of Knowledge and Future Research Directions on Formation, Abundance, Fate, and Importance. Environ. Sci. Technol. 2020. https://doi.org/10.1021/acs.est.9b06751.

(8) Brüggemann, M.; van Pinxteren, D.; Wang, Y.; Yu, J. Z.; Herrmann, H. Quantification of Known and Unknown Terpenoid Organosulfates in PM10 Using Untargeted LC-HRMS/MS: Contrasting Summertime Rural Germany and the North China Plain. Environmental Chemistry 2019. https://doi.org/10.1071/EN19089.

(9) Lee, C. P.; Riva, M.; Wang, D.; Tomaz, S.; Li, D.; Perrier, S.; Slowik, J. G.; Bourgain, F.; Schmale, J.; Prevot, A. S. H.; Baltensperger, U.; George, C.; El Haddad, I. Online Aerosol Chemical Characterization by Extractive Electrospray Ionization-Ultrahigh-Resolution Mass Spectrometry (EESI-Orbitrap). Environ. Sci. Technol. 2020. https://doi.org/10.1021/acs.est.9b07090.

(10) Riva, M.; Brüggemann, M.; Li, D.; Perrier, S.; George, C.; Herrmann, H.; Berndt, T. The Capability of $\mathrm{Cl}$-Orbitrap for Gas-Phase Analysis in Atmospheric Chemistry: A Comparison with the Cl-APiTOF Technique. Anal. Chem. 2020. https://doi.org/10.1021/acs.analchem.0c00111. 